\title{
Distinction in gene expression profiles demonstrated in parathyroid adenomas by high-density oligoarray technology
}

Lars Forsberg $^{1,2}$, Erik Björck ${ }^{1}$, Jamileh Hashemi ${ }^{1}$, Jan Zedenius ${ }^{3}$, Anders Höög ${ }^{4}$, Lars-Ove Farnebo ${ }^{2}$, Mark Reimers ${ }^{5}$ and Catharina Larsson ${ }^{1}$

${ }^{1}$ Department of Molecular Medicine, Karolinska University Hospital CMM L8:01, SE-17176 Stockholm, Sweden, ${ }^{2}$ Department of Surgical Sciences, Karolinska University Hospital P9:03, SE-17176 Stockholm, Sweden, ${ }^{3}$ Department of Surgery, Center for Metabolism and Endocrinology, Karolinska University Hospital K54, SE-14186 Stockholm, Sweden, ${ }^{4}$ Department of Oncology and Pathology, Karolinska University Hospital P1:O2, SE-17176 Stockholm, Sweden and ${ }^{5}$ Center for Genomics and Bioinformatics, Karolinska Institutet, SE-17177 Stockholm, Sweden

(Correspondence should be addressed to L Forsberg or C Larsson, Department of Molecular Medicine, Karolinska University Hospital CMM L8:O1, SE-17176 Stockholm, Sweden; Email: Lars.Forsberg@cmm.ki.se or Catharina.Larsson@cmm.ki.se)

\begin{abstract}
Objectives: Somatic deletion of chromosome 11q13 is the most frequent genetic aberration in parathyroid adenoma. To gain further insight into the genetic etiology of parathyroid tumor development, we examined a comprehensive gene expression profile of parathyroid adenomas and normal parathyroid tissues. The results were then evaluated with respect to differences between adenomas and normal parathyroid tissue, and to the presence of loss of heterozygosity (LOH) in chromosomal region 11q13. Design and methods: Sporadic parathyroid adenomas and normal parathyroids were hybridized against HG-U95 Av2 oligonucleotide arrays (Affymetrix) containing a total of 12625 probe sets. Quantitative real-time PCR (QRT-PCR) was performed in a larger series of parathyroid adenomas, in order to confirm the microarray results.

Results: Cyclin D1 and c-Jun showed increased expression in adenomas vs normal parathyroids by microarray analysis and QRT-PCR, suggesting an oncogenic role of these genes in parathyroid tumor development. At unsupervised hierarchical clustering, the adenomas fell into two groups: Group I adenomas were characterized by 11q13 LOH, while Group II adenomas lacked this abnormality. In addition, a $t$-test analysis identified largely non-overlapping genes with differential expression in the tumors subgroups; e.g. in Group I tumors the putative oncogene ENC 1 was found highly overexpressed vs Group II adenomas.

Conclusions: The microarray analyses revealed partly distinctive and partly common expression profiles in parathyroid adenomas with and without 11q13 LOH. In addition, approximately half of the under-expressed genes were mapped to chromosome 11, in agreement with a dose effect following loss of this chromosome.
\end{abstract}

European Journal of Endocrinology 152 459-470

\section{Introduction}

Primary hyperparathyroidism (PHPT) is the second most common endocrinopathy following diabetes. In the typical form, a benign adenoma overproduces parathyroid hormone (PTH) leading to hypercalcemia and symptoms following therefrom. Parathyroid tumors are also recognized in a variety of less common conditions, in which one or more glands can be involved and the tumors may be benign or malignant. In addition to the more common sporadic cases, various familial forms have also been recognized, such as multiple endocrine neoplasia type 1 (MEN 1), the hyperparathyroidism-jaw tumor syndrome (HPT-JT) and familial isolated hyperparathyroidism (FIHP). To date, a number of parathyroid tumor-related genes have been identified. For the hereditary disorders, these include germline mutations of the MEN1 gene in MEN 1 and FIHP, of CASR in familial hypocalciuric hypercalcemia variants and of HRPT2 in HPT-JT and FIHP (1-5).

In sporadic forms of the disease, inactivation of HRPT2 is preferentially found in the malignant cases while MEN1 inactivation is mainly found in the benign form (3, 6-8). Furthermore, the Cyclin D1 gene as well as several genes related to calcium homeostasis have been suggested to be involved in the development of PHPT $(9-11)$. Somatic deletion of chromosome 11 is the most frequent genetic aberration in parathyroid adenoma, and has been demonstrated by both comparative genomic hybridization (CGH) and loss of heterozygosity (LOH) techniques $(12-14)$. This alteration is seen in a third of the tumors, and generally represents a quite specific chromosomal alteration accompanied by inactivating mutation 
of the MEN1 gene in the other allele $(6,15)$. In addition, losses of chromosomes 1p, 6q, 9p, 11p, 13q and $15 q$ as well as gains of chromosomes $7,16 \mathrm{p}$ and $19 \mathrm{p}$ are also demonstrated in sporadic hyperparathyroidism $(12,13,16)$.

In the present study, we have characterized the global gene expression profiles in a series of sporadic parathyroid adenomas, in an attempt to obtain an improved picture of the genetic etiology behind parathyroid tumor development.

\section{Materials and methods}

\section{Clinical cases}

Seventeen parathyroid tumors (T1-T17) were collected from patients treated surgically for PHPT at the Karolinska University Hospital (Table 1). Informed consent was obtained from each patient and the local ethics committee approved the study of the clinical material. All patients had a sporadic form of the disease without a personal or family history of MEN 1, HPT-JT or other familial forms of PHPT. The tumors were classified histopathologically as uniglandular parathyroid adenomas according to WHO criteria (17). Representative sections were analysed to ensure that the samples used for DNA and RNA extractions contained a sufficient proportion of tumor cells for the analysis (i.e. $>70 \%$ ). Tumors $\mathrm{T} 1-\mathrm{T} 8$ were analysed by microarray, $\mathrm{LOH}$ and $\mathrm{CGH}$, while tumors $\mathrm{T} 1-\mathrm{T} 17$ were all analysed by real-time PCR. The two biopsies from normal parathyroid glands (N1 and N2) were obtained from patients treated for nodular thyroid lesions when

Table 1 Clinical data for the 17 cases with sporadic uniglandular parathyroid adenoma in this study.

\begin{tabular}{|c|c|c|c|c|c|c|}
\hline \multicolumn{2}{|c|}{ Case } & \multirow[b]{2}{*}{$\mathrm{Age}^{\mathrm{a}}$} & \multirow[b]{2}{*}{ Sex } & \multirow[b]{2}{*}{$\mathrm{S}-\mathrm{Ca}^{\mathrm{b}}$} & \multirow[b]{2}{*}{ S-PTH ${ }^{c}$} & \multirow{2}{*}{$\begin{array}{c}\text { Tumor } \\
\text { weight }(\mathrm{g})\end{array}$} \\
\hline No. & Id. & & & & & \\
\hline $\mathrm{T} 1$ & 3161 & 55 & $M$ & 2.77 & 108 & 0.85 \\
\hline $\mathrm{T} 2$ & 1879 & 53 & $\mathrm{~F}$ & 2.94 & 111 & 1.62 \\
\hline T3 & 2076 & 40 & $F$ & 2.86 & 79 & 2.38 \\
\hline $\mathrm{T} 4$ & 3648 & 59 & $M$ & 2.65 & 74 & 0.30 \\
\hline T5 & 3046 & 63 & $M$ & 2.85 & 79 & 4.44 \\
\hline T6 & 2877 & 52 & $\mathrm{~F}$ & $1.41^{*}$ & 91 & 1.70 \\
\hline T7 & 2613 & 53 & $\mathrm{~F}$ & 3.00 & 105 & 2.77 \\
\hline T8 & 3480 & 25 & $\mathrm{~F}$ & 2.66 & 284 & 0.65 \\
\hline T9 & 3575 & 75 & $\mathrm{~F}$ & $1.47^{\star}$ & $>100$ & 1.44 \\
\hline $\mathrm{T} 10$ & 3223 & 53 & $\mathrm{~F}$ & 2.75 & 88 & 0.46 \\
\hline $\mathrm{T} 11$ & 3355 & 58 & $M$ & 2.60 & 60 & 1.15 \\
\hline $\mathrm{T} 12$ & 3371 & 46 & $\mathrm{~F}$ & 3.16 & 176 & 4.00 \\
\hline T13 & 3261 & 47 & $M$ & 2.84 & 80 & 1.33 \\
\hline $\mathrm{T} 14$ & 2896 & 34 & $M$ & 2.70 & 66 & 0.39 \\
\hline $\mathrm{T} 15$ & 2766 & 65 & $\mathrm{~F}$ & 2.50 & 140 & 1.13 \\
\hline T16 & 2884 & 82 & $M$ & $1.50^{*}$ & 172 & 2.08 \\
\hline $\mathrm{T} 17$ & 3647 & 83 & $\mathrm{~F}$ & 2.75 & 174 & 2.30 \\
\hline
\end{tabular}

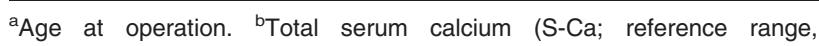
$2.20-2.60 \mathrm{mmol} / \mathrm{l}$ ) preoperatively. ${ }^{*} \mathrm{~S}-\mathrm{Ca}$ level originally reported as ionized $\mathrm{Ca}$ (reference range, $1.15-1.35 \mathrm{mmol} / \mathrm{l})$. Intact serum PTH (S-PTH; reference range, $17-55 \mathrm{ng} / \mathrm{l})$ preoperatively. parathyroid glands had to be excised and reimplanted into the sterno-mastoid muscle for anatomical reasons. Both these patients had normal levels of PTH, serum calcium and thyroid hormones preoperatively. They were both verified as histopathologically normal, and were used as reference samples in the microarray and real-time PCR analysis.

\section{Isolation of DNA and RNA}

All tissue samples were collected immediately after surgery and stored at $-70^{\circ} \mathrm{C}$ until use. Total RNA was extracted from all 17 tumors (T1-T17) and the two normal parathyroid biopsies (N1 and N2) using the TRIzol reagent (Invitrogen, Carlsbad, CA, USA), followed by purification with an Rneasy mini kit (Qiagen, Hilden, Germany). The RNA purity and quality was confirmed by analysis in an Agilent 2100 Bioanalyser (Agilent Technnologies, Inc, Paolo Alto, CA, USA). For eight of the adenomas $(\mathrm{T} 1-\mathrm{T} 8)$, DNA was isolated in parallel with the RNA during the TRIzol extraction. Peripheral blood leukocytes were used as a source of constitutional DNA in the microsatellite analysis (T1-T8).

\section{LOH analyses}

The eight matched blood and tumor DNA samples from $\mathrm{T} 1$ - T8 were genotyped for three microsatellite markers located at the MEN1 locus in 11q13: cen(D11S4946/MEN1)- D11S4938-D11S4937-tel. For $\mathrm{T} 2$ and $\mathrm{T} 3, \mathrm{LOH}$ analyses of markers from the MEN1 region have been previously published (15). The markers were analysed using fluorescent detection in an ABI 377 laser fluorescent sequencer and the GeneScan 3.1 software (Applied Biosystems, Perkin Elmer Corp., Foster City, CA, USA).

\section{Microarray experiments and data analyses}

For eight of the tumors (T1-T8) and the two normal biopsies (N1 and N2), cDNA was synthesized from total RNA using a T-7 linked oligo-dT primer, and then used for cRNA synthesis with biotinylated UTP and CTP. After fragmenting, the labeled RNA was hybridized to HG-U95Av2 oligonucleotide arrays (Affymetrix Inc., Santa Clara, CA, USA) according to the protocol recommended by the supplier. After hybridization, the arrays were washed and stained with streptavidinphycoerythrin (Molecular Probes, Inc., Eugene, OR, USA) in an Affymetrix fluidics station. The arrays were then scanned in an Affymetrix scanner and the expression values for each probe set (represented by 16-20 selected oligomers) were estimated using the Affymetrix Microarray Suite Software (MAS v5.0). To minimize discrepancies resulting from individual variations regarding sample preparations, hybridization conditions, staining or different oligoarray lots, all probe sets were scaled from each array to a target 
intensity value of 100 (using Affymetrix MAS v5.0), thus allowing interarray comparisons. Scaling factors (range 2.28-5.26) varied within the acceptable range i.e. $<$ threefold. $3^{\prime} / 5^{\prime}$ ratios for GAPDH and $\beta$-actin were confirmed to be within acceptable limits $(<$ threefold), and BioB spike controls were found to be present on all chips. In addition, the internal controls BioC, BioD and CreX were present in increasing intensity.

By using the statistical detection algorithm in Affymetrix MAS v5.0, we were able to separate the transcripts of particular probe sets that are reliably detected (present call), from the transcripts below the threshold of detection and therefore considered as absent. From the 12626 probe sets on the array, control probes and genes scored as marginal or absent (not detected) were excluded, leaving 4436 present probe sets for the subsequent analyses.

Comparison files were created using the batch analysis tool in the MAS v5.0. These included files for each of the parathyroid adenomas (T1-T8), which were then individually compared with each of the normal parathyroids (N1and N2), thus yielding 16 comparison files. To identify differentially expressed genes between parathyroid adenomas and normal parathyroids, two different algorithms from the MAS v5.0 tool were applied. The change algorithm reported the probe sets to be unchanged, increased, decreased or marginal. The signal log ratio algorithm instead calculated an estimated log value for each probe set in each sample. The algorithms are described at http://www. affymetrix.com/support/technical/technotes/statistical _reference_guide.pdf. For both algorithms the signal values were imported into the GeneSpring 5.0 software tool (Silicon Genetics, Redwood City, CA, USA) to sort out genes with increased or decreased expression. Unsupervised hierarchical clustering analysis of the 4436 present probe sets was performed using GeneSpring 5.0 software with the minimum distance set to 0.001 and the separation ratio set to 0.95 . The comparisons of mean expression levels were compared in the two groups of tumors identified by clustering, i.e. T1-T4 with 11q13 LOH (Group I) and T5-T8 without $11 q 13$ LOH (Group II). The comparisons were carried out using the expression values estimated by dChip analysis (www.dchip.org) (18). This was done to obtain more sensitive estimates of the low-abundance genes than were available through MAS v5.0. To avoid effects related to the wide variation at the upper end of the distribution of values, the logarithmic values were used. $t$-statistics were computed for each gene between the two groups of tumors identified by clustering. The false positive rate was estimated at several different thresholds for the $t$-score, by permutating the sample labels and re-computing all gene-wise $t$-scores. The $t$-score threshold was set so that the estimated number of false positives was half the number of genes with $t$-scores exceeding that threshold (i.e. the 'false discovery rate' was one half).

\section{CGH}

CGH was carried out on tumors $\mathrm{T} 1-\mathrm{T} 8$ using methods previously described (13). For T2 and T3 the results have been previously published (13). A minimum of ten three-color digital images (DAPI, FITC and Spectrum Red fluorescence) were captured from each hybridization using an Axioplan 2 epifluorescence microscope (Carl Zeiss Jena GmbH, Jena, Germany) equipped with a Sensys charged-coupled-device camera (Photometrics, Tucson, AZ, USA) and analysed with the isis/CGH software (Metasystem, Altlussheim, Germany). Relative DNA sequence copy number changes were detected along the length of all chromosomes in each metaphase spread. Green to red ratios $<0.8$ were scored as losses, ratios $>1.2$ as gains and ratios $>2.0$ as high-level amplifications. Heterochromatic regions in the centromeric and paracentromeric parts of some chromosomes, the $\mathrm{Y}$ chromosome, the short arm of the acrocentric chromosomes as well as the region next to the telomeres were not included in the evaluation. All tumor samples were hybridized and analysed on two different occasions, with concordant results.

\section{Quantitative real-time PCR (QRT-PCR)}

Total RNA was isolated from T1-T17 and N1 and N2 as described above. To avoid the presence of genomic DNA all samples were treated with DNAase after RNA extraction. Ten micrograms of RNA were reverse transcribed into cDNA using the TaqMan reverse transcription Kit (Applied Biosystems). Reverse transcription was performed in a thermal cycler at $25^{\circ} \mathrm{C}$ for $10 \mathrm{~min}$ and $37^{\circ} \mathrm{C}$ for $120 \mathrm{~min}$. For five of the six genes analysed by TaqMan real-time PCR, Assays-on-Demand kits (Applied Biosystems) were available including Cyclin D1 (assay identification (ID) is HsO0233498_m1), c-Jun (HsO0277190_s1), $\beta$-actin (Hs99999903_m1), TBP (Hs99999910_m1) and 18S rRNA (Hs99999901_s1). For each single sample, the mastermix included: $12.5 \mu \mathrm{l}$ TaqMan $2 \times$ Universal MasterMix (Applied Biosystems), $8.25 \mu \mathrm{l}$ RNAse-free water and $1.25 \mu \mathrm{l} 20 \times$ Assays-on-Demand gene expression assay mix. For the 36B4 gene (public ID M17885) no Assays-on-Demand are available, while the following previously published primers and probe were used (19): forward primer: 5'-AGATGCAGCAGATCCGCAT-3'; reverse primer: 5'-ATATGAGG AGCAGTTTCTCCAG-3'. The corresponding TaqMan probe 5'-AGGCTGTGGTGCTGATGGGCAAGAAC-3' was purchased from MedProbe (catalogue number OL-0361-FAMDQ02). For 36B4, the TaqMan PCR Master-Mix was constituted of $12.5 \mu \mathrm{l}$ TaqMan $2 \times$ Universal Master-Mix, $7 \mu$ l RNAse free water, $1.5 \mu \mathrm{l}$ primers $(10 \mu \mathrm{M})$ and $1 \mu \mathrm{l} 36 \mathrm{~B} 4$ probemix ( $5 \mu \mathrm{M}$;) per sample to be analysed. For each sample and gene, $22 \mu \mathrm{l}$ aliquots of the MasterMix and $3 \mu \mathrm{l}$ $(\sim 15 \mathrm{ng})$ cDNA were transferred in duplicates to 
adjacent wells of a MicroAmp Optical 96-well reaction plate (Applied Biosystems) and covered with Optical Caps (Applied Biosystems). The plate was then placed in the ABI Prism 7700 Sequence Detector (Applied Biosystems) and the run commenced. The conditions for every TaqMan PCR reaction were: $2 \mathrm{~min}$ at $50^{\circ} \mathrm{C}$ (stage 1$), 10 \mathrm{~min}$ at $95^{\circ} \mathrm{C}$ (stage 2) and 40 cycles of $15 \mathrm{~s}$ at $95^{\circ} \mathrm{C}$ followed by $60 \mathrm{~s}$ at $60^{\circ} \mathrm{C}$ (stage 3 ). When the run was completed, output data were analysed using the SDS software and exported into a Microsoft Excel file for analysis. The 36B4 housekeeping gene was used as an endogenous control to normalize the expression level of target genes. Standard curves for $36 B 4$ and target genes were constructed using 1:10 serial dilutions of control cDNA prepared from the human neuroblastoma cell-line SK-NAS.

In the fold-change analysis, the RNA level was standardized by correcting for the 3634 level in the same sample. For all experimental samples (T1-T17), the quantity was determined from the standard curve and divided by the quantity of the mean normal quantity $(\mathrm{N} 1 / \mathrm{N} 2)$. Thus, the normal quantity becomes the $1 \times$ sample, and all other quantities are expressed as a relative $n$-fold difference.

\section{Results}

Expression profiling was performed on eight parathyroid adenomas (T1-T8) and two normal parathyroid tissues (N1 and N2) by hybridization to high-density oligonucleotide arrays. Some of the array results were then verified by QRT-PCR in an extended series of 17 sporadic parathyroid adenomas (T1-T17). The clinical details of the 17 cases with PHPT are listed in Table 1. The findings and expression analyses are illustrated in Fig. 1 and Tables 2-5.

\section{Comparison of parathyroid adenomas and normal parathyroid}

A total of 4436 of the 12625 probe sets represented on the array gave a present call in at least eight of the ten arrays. This set of present genes was considered as informative and used in all comparisons in this study. However, for the analysis of the genes with decreased expression in the adenomas, the 4533 genes detected as present in both normal parathyroids were included in the analysis.

Differentially expressed genes between parathyroid adenomas (T1-T8) and normal parathyroids (N1 and N2) were identified by pair-wise comparison using change and signal log ratio algorithms in the Affymetrix MAS v5.0. The computing results from both analyses were then imported into the GeneSpring software tool, in order to identify probe sets with increased or decreased expression. A total of 224 probe sets showed increased expression in the adenomas vs normal parathyroids using at least one of the algorithms. The 35 probe sets (representing 31 genes) that were independently identified with increased expression in the adenomas using both algorithms are listed in Table 2. Several of the over-expressed genes are putative oncogenes involved in cell cycle control or transcriptional regulation, e.g. the Cyclin D1 gene and the c-Jun proto-oncogene. Similarly, 361 probe sets were detected with decreased expression in the adenomas by at least one algorithm. Eighty of these (representing 75 genes) were identified as decreased by both algorithms (Table 4). Noteworthy, CACNB2 and CXCL12 involved in calcium transport and homeostasis were present among these genes with decreased expression.

\section{Expression of parathyroid-related genes}

In addition, we investigated the microarray expression of genes selected because of their demonstrated or implicated relation to parathyroid functions (Table 3). The calcium-sensing receptor gene (CASR) showed a distinct pattern of decreased expression in all eight adenomas. The mean expression level was 0.61 (range 0.43-0.80) as compared with the mean expression of the two normal parathyroids (1.00). Similarly, a reduced expression was noted for the vitamin D receptor gene (VDR), with a mean reduction from 1.0 in the normal parathyroids to 0.47 (range 0.20-0.64) in the eight adenomas.

\section{Different expression profiles in parathyroid adenomas with and without 11 q13 $\mathrm{LOH}$}

Similarities in the global gene expression patterns of normal and pathological parathyroids were studied by creating a hierarchical tree. The unsupervised hierarchical clustering analysis of the present probe sets (4436) revealed that the eight tumor samples fell into two distinct cluster groups (Fig. 1A). Group I was found to consist of the four tumors with $11 \mathrm{q} 13 \mathrm{LOH}$ (T1-T4) and Group II of the four tumors without $11 \mathrm{q} 13 \mathrm{LOH}$ (T5-T8). The expression profiles between the tumors in the two groups were then compared by direct $t$-test comparisons of the means between the two groups. The $t$-tests revealed 85 genes that showed significantly $(P<0.0032)$ differential mean expression between the two groups (Table 5). The results obtained from the two independent approaches (MAS v5.0: Fig. 1 and dChip: Table 5) support the distinction in expression between Group I and Group II adenomas.

As is evident from Table 5, approximately $50 \%$ of the genes with decreased expression in Group I vs Group II were located on chromosome 11 within and outside the q13 region (Fig. 1B). This indicated that the lower expression of some genes in Group I could be a result of low DNA dose, i.e. a reduction in DNA copies. In 
A

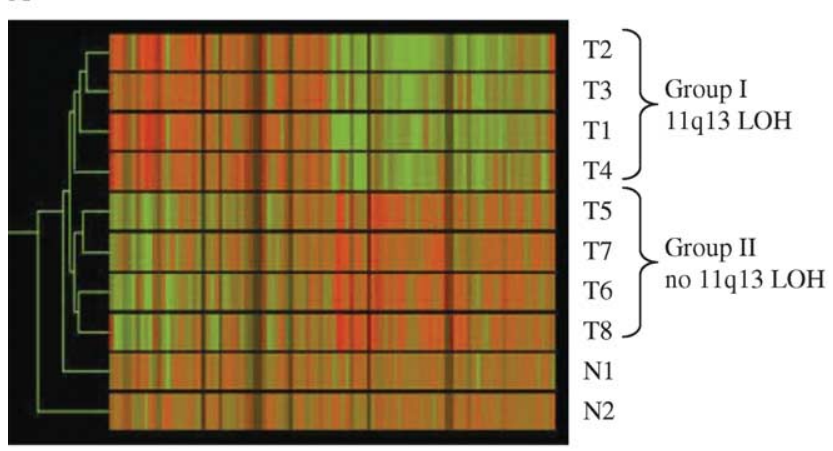

C

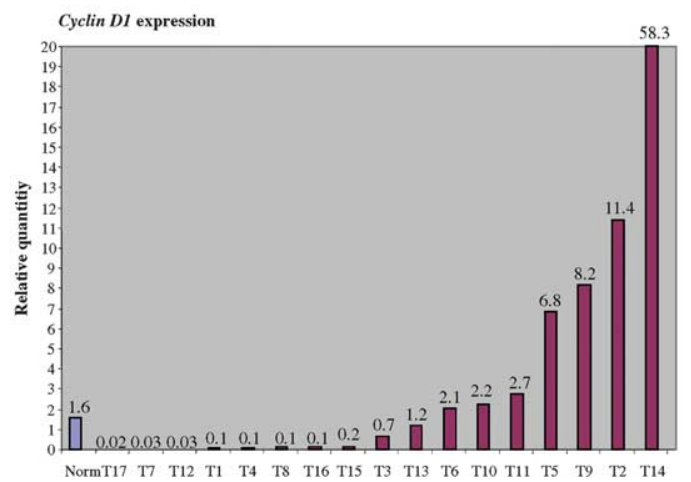

B

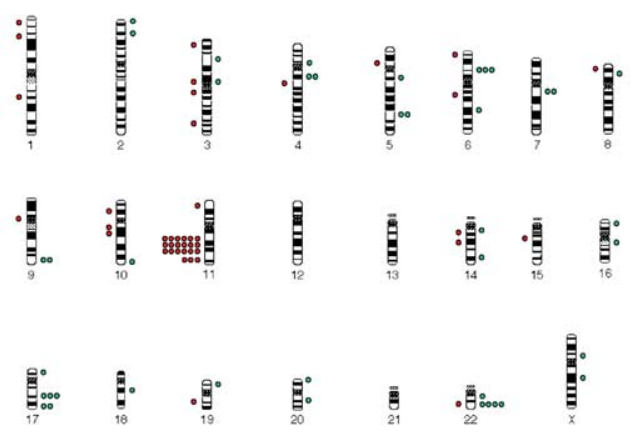

$\mathrm{D}$

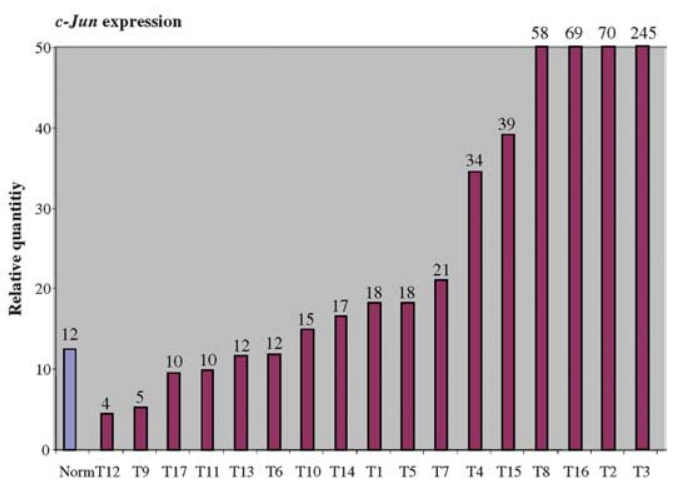

Figure 1 (A) Unsupervised hierarchical clustering of the eight parathyroid adenomas (T1-T8) and two normal parathyroids (N1 and N2) analyzed by microarray. All probe sets that were present in at least eight of the ten arrays, i.e. 4436, were used to create the hierarchical tree. The dendogram was based on MAS v5.0 estimates. The hierarchical tree revealed two distinct cluster subgroups, which were found to consist of the four tumors with $11 \mathrm{q} 13 \mathrm{LOH}$ (Group I) and the four with no 11q13 LOH (Group II). All eight adenomas were distinctly separated from the two normal parathyroids (N1 and N2). The highlighted genes showed significantly altered expression in Group I vs Group II adenomas based on dChip estimates (Table 5). Red indicates relatively higher and green indicates relatively lower gene expression. (B) Chromosomal location of the 85 genes showing significantly $(P<0.0032)$ differential mean expression between adenoma Groups I and II. The $t$-tests were performed by comparing the mean expression levels between Group I and Group II using the dChip software. Genes detected with increased expression in Group I compared with Group II are shown by green circles to the right of the chromosomes, whereas those with decreased expression are shown by red circles to the left. (C and D) QRT-PCR analysis of the RNA expression levels of (C) Cyclin D1 and (D) C-Jun in normal parathyroid (Norm) and parathyroid adenomas (T1-T17). The results presented represent the mean of duplicate PCR assays and after normalization against the housekeeping gene 36B4. Norm shows the average expression level from the two normal parathyroids analysed (N1 and N2). The numbers above the bars are relative quantities.

addition, no gene located on chromosome 11 was detected with increased expression when comparing the adenomas in Group I vs Group II. In order to detect the chromosome 11 status in the adenomas used for array analyses we complemented the LOH analysis with CGH. Of the eight adenomas hybridized onto microrarrays, tumors $\mathrm{T} 1-\mathrm{T} 4$ were by $\mathrm{LOH}$ performance identified with a deletion in 11q13 while T5-T8 had retention of the same chromosomal region. CGH results confirmed that the entire chromosome 11 was lost in three (T1-T3) of the four tumors in Group I. In T4, no loss of 11 was detected by CGH, suggesting that tumor T4 carries a balanced alteration or a small deletion of chromsome 11q13 beyond the resolution of CGH. The four adenomas in Group II (T5-T8) all showed retention of chromosome 11 by CGH. In addition, losses were detected in 1p32-ter (T4), 6cenq22 (T4), 15q (T3, T8), 21q (T3, T8) and 22q (T8), while trisomies were observed for chromosomes 6,8 , 14 and 16 (T7).

\section{QRT-PCR analyses of selected genes}

Two genes (Cyclin D1 and c-Jun), detected with increased expression in tumors vs normal parathyroid by the array analysis, were selected for QRT-PCR on a larger series of sporadic parathyroid tumors, including 17 adenomas T1-T17 (Table 1) and two normal parathyroid biopsies (N1 and N2). In these analyses, the quantity of the tumor cDNA was determined from the standard curve and divided by the quantity of the normal parathyroid. The 36B4 housekeeping gene was used as an endogenous control to normalize the expression level of target genes. Cyclin D1 thus showed more than twofold increased expression in 4/17 (24\%) of the adenomas compared with the average expression of the two 
Table 2 Genes with increased expression in parathyroid adenomas (T1-T8) vs normal parathyroids (N1 and N2).

\begin{tabular}{|c|c|c|c|c|}
\hline Accession number & Gene symbol & Chromosomal location & GO biological process description ${ }^{a}$ & Probe set ID \\
\hline J04111 & c-JUN & 1p32-p31 & Regulation of transcription & 32583 at \\
\hline J04111 & c-JUN & 1p32-p31 & Regulation of transcription & 1895_at \\
\hline AF065388 & TSPAN-1 & $1 \mathrm{p} 34.1$ & Cell proliferation and adhesion & 34775_at \\
\hline M97815 & CRABP-II & $1 \mathrm{q} 21.3$ & Regulation of transcription & 1057_at \\
\hline X57985 & HIST2H2BE & $1 \mathrm{q} 21-\mathrm{q} 23$ & Regulation of transcription & 33352 at \\
\hline M82809 & ANXA4 & $2 \mathrm{p} 13$ & & 37374_at \\
\hline U17077 & $B E N E$ & $2 q 13$ & & 33331_at \\
\hline X05323 & MOX2 & $3 q 12-q 13$ & & 37716 at \\
\hline D16815 & NRID2 & 3p24.1 & Regulation of transcription & 35705_at \\
\hline D16815 & NRID2 & 3p24.1 & Regulation of transcription & 35706_at \\
\hline AF049884 & $A R G B P 2$ & $4 q 35.1$ & & 39295_s_at \\
\hline M31661 & PRLR & $5 p 14-p 13$ & Embryo implantation & 1078 at \\
\hline X68742 & ITGA1 & $5 q 11.1$ & Cell-matrix adhesion & 120 at \\
\hline X70683 & SOX4 & $6 p 22.3$ & Regulation of transcription & 33131_at \\
\hline X78947 & CTGF & $6 \mathrm{q} 23.1$ & Regulation of cell growth & 36638_at \\
\hline AL033377 & & $6 q 23.1-q 24.3$ & Neuropeptide signalling & 36014 at \\
\hline M15518 & PLAT & $8 \mathrm{p} 12$ & Protein modification & 33452 at \\
\hline D84111 & RBPMS & $8 p 12-p 11$ & RNA processing & 34162_at \\
\hline D84111 & RBPMS & $8 \mathrm{p} 12-\mathrm{p} 11$ & RNA processing & 34163_g_at \\
\hline U90878 & PDLIM1 & $10 \mathrm{q} 22-\mathrm{q} 26.3$ & Intracellular signalling & 36937 a at \\
\hline X76488 & LIPA & $10 \mathrm{q} 23.2-\mathrm{q} 23.3$ & Lipid catabolism & 38745 at \\
\hline M64349 & CCND1 & $11 \mathrm{q} 13$ & Regulation of cell cycle & 2017_s_at \\
\hline W28869 & TEGT & $12 \mathrm{q} 12-\mathrm{q} 13$ & Apoptosis & $33989 \mathrm{f}$ at \\
\hline U82256 & ARG2 & $14 \mathrm{q} 24.1-\mathrm{q} 24.3$ & Urea cycle catabolism & 32722 at \\
\hline D31885 & $A R L 6 I P$ & $16 \mathrm{p} 11.2-\mathrm{p} 12$ & & $36572 \mathrm{r}$ at \\
\hline Y00503 & KRT19 & $17 q 21$ & & 40899_at \\
\hline AF002020 & NPC1 & $18 \mathrm{q} 11-\mathrm{q} 12$ & Protein transport & 37047 at \\
\hline AF002020 & NPC1 & $18 \mathrm{q} 11-\mathrm{q} 12$ & Protein transport & 980 at \\
\hline D00096 & TTR & $18 \mathrm{q} 12.1$ & Thyroid transport & 32252_at \\
\hline A1263885 & WSX1 & $19 p 13.11$ & Immune response & 37844_at \\
\hline U87947 & EMP3 & $19 q 13.3$ & Regulation of cell growth & 39182 at \\
\hline M68840 & MAOA & Xp11.4-p11.3 & Neurotransmitter catabolism & 41772_at \\
\hline M68840 & $M A O A$ & X911.4-p11.3 & Neurotransmitter catabolism & 41771_g_at \\
\hline AL049250 & & $16 \mathrm{p} 12.2$ & & 40951_at \\
\hline AF052107 & LOC129642 & $2 \mathrm{p} 25.1$ & & 38262_at \\
\hline
\end{tabular}

All genes listed were, in pairwise comparison, identified with increased expression using two algorithms in MAS v5.0. ${ }^{\mathrm{a}} \mathrm{Gene}$ ontology description according to the NetAffxTM analysis center: http://www.affymetrix.com/analysis/index.affx

Table 3 Relative expression levels of selected genes with parathyroid-related functions in adenomas as compared with normal parathyroid.

\begin{tabular}{lccc}
\hline Case number & $\begin{array}{c}\text { CASR } \\
(3 q 21-q 24)\end{array}$ & $\begin{array}{c}\text { PTH } \\
(11 p 15)\end{array}$ & $\begin{array}{c}\text { VDR } \\
(12 q 12-q 14)\end{array}$ \\
\hline Group I: With 11q13 LOH & & & \\
T1 & 0.48 & 0.51 & 0.64 \\
T2 & 0.46 & 0.35 & 0.51 \\
T3 & 0.60 & 0.70 & 0.47 \\
T4 & 0.72 & 0.70 & 0.49 \\
Group II: no 11q13 LOH & & & \\
T5 & 0.80 & 1.76 & 0.54 \\
T6 & 0.43 & 1.10 & 0.50 \\
T7 & 0.76 & 0.94 & 0.38 \\
T8 & 0.66 & 0.84 & 0.20 \\
Normal parathyroids & & & \\
Average of N1 and N2 & 1.00 & 1.00 & 1.00 \\
Range of N1/N2 & $1.00 / 1.00$ & $0.95 / 1.05$ & $1.21 / 0.79$ \\
\hline
\end{tabular}

$\mathrm{CASR}=$ calcium sensing receptor. Probe set ID 38958_at/accession number U20760.

$\mathrm{PTH}=$ parathyroid hormone: 708 at/J00301. VDR $=$ vitamin $\mathrm{D}$ receptor: $1388 \mathrm{~g}$ at/J03258. normal parathyroid samples (Fig. 1C). Similarly, c-Jun showed more than a twofold increased expression in $6 / 17(35 \%)$ of the adenomas (Fig. 1D).

\section{Discussion}

In approaching the molecular genetic pathways of parathyroid tumor development we have characterized global expression profiles in parathyroid adenomas and normal parathyroid tissues, using the oligonucleotide microarray technology. Although the number of samples studied was limited, several significant results were obtained. We could identify genes that were differentially expressed in tumors vs normal tissue. We also investigated the expression profiles of selected genes, previously implicated in parathyroid-related functions, and observed altered expression profiles for some of them. In addition, we detected different expression patterns in parathyroid adenoma subgroups. 
Table 4 Genes with decreased expression in parathyroid adenomas (T1-T8) vs normal parathyroid (N1 and N2).

\begin{tabular}{|c|c|c|c|c|}
\hline Accession number & Gene symbol & Chromosomal location & GO biological process description ${ }^{a}$ & Probe set ID \\
\hline X08020 & GSTM1 & $1 \mathrm{p} 13.3$ & & 39054_at \\
\hline U20938 & $D P Y D$ & $1 \mathrm{p} 22$ & & 38220_at \\
\hline AL049798 & $D P T$ & $1 q 12-q 23$ & Cell adhesion & 38057_at \\
\hline Z97171 & MYOC & $1 q 23-q 24$ & Vision morphogenesis & 40403_at \\
\hline M25280 & SELL & $1 \mathrm{q} 23-\mathrm{q} 25$ & Cell motility & 245_at \\
\hline AB007972 & PP1R12B & $1 \mathrm{q} 32.1$ & Signal transduction & 41137_at \\
\hline M69199 & Gos2 & $1 q 32.2-q 41$ & Regulation of cell cycle & 38326_at \\
\hline M81883 & GAD1 & $2 q 31$ & Glutamate decarboxylation & 37183_at \\
\hline X51408 & CHN1 & $2 q 31-q 32.1$ & Intracellular signalling & 40512_at \\
\hline AJ001014 & RAMP1 & $2 q 36-q 37.1$ & Intracellular signalling & 35668_at \\
\hline S95936 & $T F$ & $3 q 21$ & Ion transport & 32538_at \\
\hline D64142 & H1FX & $3 q 21.3$ & Regulation of transcription & 318_at \\
\hline AF035296 & $D C 12$ & $3 q 21.3$ & & 38989_at \\
\hline J02611 & $A P O D$ & 3q26.2-qter & Lipid metabolism & 36681_at \\
\hline D45371 & APM1 & $3 q 27$ & Energy pathways & 40658_r_at \\
\hline U51712 & $H O P$ & $4 q 11-q 12$ & & 39698_at \\
\hline M12963 & $A D H 1 A$ & $4 q 21-q 23$ & Alcohol metabolism & 34637_f_at \\
\hline X03350 & $A D H 1 B$ & $4 q 21-q 23$ & Alcohol metabolism & 35730_at \\
\hline AL049963 & SLC39A8 & $4 q 22-q 24$ & Ion transport & 40456_at \\
\hline D45299 & $B A S P 1$ & $5 p 15.1-p 14$ & Regulation of transcription & 32607_at \\
\hline AB005060 & NRG2 & $5 q 23-q 33$ & Regulation of transcription & 35089_at \\
\hline X68277 & DUSP1 & $5 q 34$ & Amino acid dephosphorylation & 1005_at \\
\hline AW015732 & AIM1 & $6 q 21$ & Cell adhesion & 32112 s_at \\
\hline$X 56777$ & ZP3 & $7 q 11.23$ & Cell adhesion & 39719_at \\
\hline AA128249 & FABP4 & $8 q 21$ & Transport & 38430_at \\
\hline N74607 & QP3 & $9 p 13$ & Transport & 39248_at \\
\hline X92493 & PIP5K1B & $9 q 13$ & & 37253_at \\
\hline Y10812 & FBP2 & $9 \mathrm{q} 22.3$ & Carbohydrate metabolism & 40293_at \\
\hline $\mathrm{S} 60415$ & CACNB2 & $10 \mathrm{p} 12$ & Calcium ion transport & 39646_at \\
\hline L36033 & CXCL12 & $10 q 11.1$ & Calcium ion homeostasis & 32666_at \\
\hline L36033 & CXCL12 & $10 \mathrm{q} 11.1$ & Calcium ion homeostasis & 33834_at \\
\hline Al381790 & APM2 & $10 q 23.31$ & & 32527_at \\
\hline X00129 & RBP4 & $10 q 23-q 24$ & & 32552_at \\
\hline D42073 & $R C N 1$ & $11 \mathrm{p} 13$ & & 40556_at \\
\hline X76732 & NUCB2 & $11 \mathrm{p} 15.1-\mathrm{p} 14$ & & 35643_at \\
\hline X57351 & IFITM2 & $11 \mathrm{p} 15.5$ & Immune response & 411_i_at \\
\hline M55409 & $E E F 1 G$ & $11 \mathrm{q} 12.3$ & & 1676_s_at \\
\hline X92814 & HRASLS3 & $11 \mathrm{q} 13.1$ & & 35704_at \\
\hline AA158243 & FKBP2 & $11 q 13.1-q 13.3$ & Protein folding & 33409_at \\
\hline S72370 & $P C$ & $11 q 13.4-q 13.5$ & Gluconeogenesis & 38000_at \\
\hline AF060568 & ZNF145 & $11 \mathrm{q} 23.1$ & & 39681_at \\
\hline AB017563 & 1GSF4 & $11 \mathrm{q} 23.2$ & & 35829_at \\
\hline AB017563 & 1GSF4 & $11 \mathrm{q} 23.2$ & & 37929_at \\
\hline U60060 & FEZ1 & $11 \mathrm{q} 24.2$ & Cell adhesion & 37743_at \\
\hline J03802 & PTHLH & $12 \mathrm{p} 12.1-\mathrm{p} 11.2$ & Cell-cell signalling & 37989_at \\
\hline J03802 & PTHLH & $12 \mathrm{p} 12.1-\mathrm{p} 11.2$ & Cell-cell signalling & 615_s_at \\
\hline J04080 & C1S & $12 \mathrm{p} 13$ & Proteolysis & 40496_at \\
\hline M12807 & $C D 4$ & 12 pter-p12 & Immune response & 35517_at \\
\hline X05409 & ALDH2 & $12 \mathrm{q} 24.2$ & Alcohol metabolism & 32747_at \\
\hline AB018273 & SACS & $13 q 12$ & & 32102 at \\
\hline L26336 & HSPA2 & $14 q 24.1$ & Spermatid development & 36925_at \\
\hline L26336 & HSPA2 & $14 \mathrm{q} 24.1$ & Spermatid development & 645_at \\
\hline V01512 & FOS & $14 \mathrm{q} 24.3$ & & 1915 s_at \\
\hline V1512 & FOS & $14 q 24.3$ & & 1916_s_at \\
\hline AF0933118 & FBLN5 & $14 q 32.1$ & Cell-matrix adhesion & 39038_at \\
\hline AF047348 & APBA2 & $15 q 11-q 12$ & Neurogenesis & 39590_at \\
\hline U90942 & MYO5A & $15 q 21$ & & 40571_at \\
\hline AB005293 & PLIN & $15 q 26$ & Lipid metabolism & 37122_at \\
\hline AL109695 & SLC03A1 & $15 q 26$ & Ion transport & 37451_at \\
\hline U07919 & $A L D H 1 A 3$ & $15 \mathrm{q} 26.3$ & Alcohol metabolism & 36686_at \\
\hline AB002351 & $D M N$ & $15 q 26.3$ & & 39544_at \\
\hline AC004381 & LOC81691 & $16 \mathrm{p} 13.11$ & & 41149_at \\
\hline K01383 & MT1G & $1 \mathrm{p} 35.1$ & & 31623_f_at \\
\hline AA224832 & MT1X & $16 q 13$ & Metal ion response & 39120_at \\
\hline D21254 & $\mathrm{CDH11}$ & $16 q 22.1$ & & 2087_s_at \\
\hline
\end{tabular}

Table 4 continued on following page 
Table 4 Continued.

\begin{tabular}{|c|c|c|c|c|}
\hline Accession number & Gene symbol & Chromosomal location & GO biological process description ${ }^{a}$ & Probe set ID \\
\hline U39447 & AOC3 & $17 q 21$ & Immune response & 33756_at \\
\hline M34064 & $\mathrm{CDH} 2$ & $18 q 11.2$ & Cell adhesion & 2053_at \\
\hline U56102 & CD226 & $18 q 22.3$ & Cell adhesion & 33575_at \\
\hline M84526 & $D F$ & $19 \mathrm{p} 13.3$ & Proteolysis & 40282_s_at \\
\hline M92843 & ZFP36 & $19 q 13.1$ & mRNA catabolism & 40448_at \\
\hline$X 73113$ & MYBPC2 & $19 q 13.33$ & Muscle contraction regulation & 37941_at \\
\hline J02854 & MYL9 & $20 q 11.23$ & Muscle contraction regulation & 39145_at \\
\hline AA181053 & PARVB & $22 q 13.2-q 13.33$ & & 37965_at \\
\hline M69177 & $M A O B$ & Xp11.4-p11.3 & Electron transport & 37628_at \\
\hline L27560 & IGFBP5 & $2 q 35$ & & 1396_at \\
\hline L27560 & IGFBP5 & $2 q 35$ & & 38650_at \\
\hline AF007153 & FLJ44318 & $2 q 34$ & & 37273_at \\
\hline \multicolumn{2}{|l|}{ HG3477-HT3670 } & & & 1146_at \\
\hline \multicolumn{2}{|l|}{ U05861 } & 10p15.1 & & 32805_at \\
\hline H15814 & & & & 40657_r_at \\
\hline
\end{tabular}

All genes listed were, in pairwise comparison, identified with decreased expression using two algorithms in MAS v5.0. ${ }^{a}$ Gene ontology description according to the NetAffxTM analysis center: http://www.affymetrix.com/analysis/index.affx

\section{Comparison of parathyroid adenomas and normal parathyroid}

The result of over-expressed genes in adenomas vs normal parathyroid identifies several putative oncogenes implicated in cell growth and transcriptional regulation, such as the Cyclin D1 gene and the c-Jun proto-oncogene (Table 2). Cyclin D1 over-expression is in agreement with the protein over-expression previously detected by immunohistochemistry in parathyroid adenomas (20, 21). A pericentric inversion with breakpoints at $11 \mathrm{q} 13$ and 11 p1 5 is suggested to bring the Cyclin D1 oncogene under the influence of the $5^{\prime}$-regulatory sequences of the PTH gene (9), which results in dramatic over-expression of Cyclin D1. While this rearrangement has been described in a few tumors only, Cyclin D1 protein overexpression has been reported in $18-40 \%$ of adenomas by immunohistochemistry studies. Cyclin D1 promotes the G1-S-phase transition, probably by activating a cyclin-dependent kinase, but may also interact with other proteins and influence other pathways related to cell proliferation (22). In our study, over-expression of Cyclin D1 and c-Jun in the adenomas vs normal parathyroid tissue was confirmed by real-time PCR, which represents an accurate method for mRNA expression quantification. In the extended series of 17 adenomas, Cyclin D1 was over-expressed ( $>$ twofold) in $24 \%$ of the cases, which is in good agreement with the reported immunohistochemistry results $(20,21)$. Notably, in the four adenomas with Cyclin D1 over-expression, the level was largely increased compared with the normal parathyroid (4- to 36-fold), suggesting its relevance for tumor development.

The c-Jun gene, located in chromosomal region $1 \mathrm{p} 32$, has previously been shown to induce oncogenic transformation, probably due to several mechanisms: c-Jun is upregulated in many carcinomas and one suggested function (e.g. in primary hepatocytes and in liver tumors) is to antagonize the proapoptotic activity of p53 (23). Furthermore, c-Jun is a member of the same family of Jun transcription factors as JunD (24). Menin, encoded by the MEN1 gene in 11q13, interacts with the AP-1 transcription factor leading to a repression of the JunD-mediated transcription (25). Interestingly, menin was recently shown to uncouple JunD and c-Jun phosporylation from MAP kinase activation (26). Given the role of MEN1 in parathyroid tumor development, it is tempting to speculate that c-Jun could also play a role in this tumor type. In our array analysis, over-expression of c-Jun was confirmed by two independent probe sets (Table 2). Furthermore, real-time PCR showed a $>$ twofold increased expression in $6 / 17$ of the adenomas (35\%) as compared with normal parathyroid.

QRT-PCR analyses was performed on two of the most interesting over-expressed genes and correlated well with the array results, thus supporting the accuracy of the array methodology applied. In the real-time PCR, the normalization to a housekeeping gene is currently the most acceptable method to correct for minor variations due to differences in RNA amounts or in efficiencies of reverse transcription. An ideal housekeeping gene should be expressed at an approximately constant level among different tissues and between, for example, tumor and normal samples. We found that the $36 \mathrm{~B} 4$ housekeeping gene (coding for the acidic ribosomal phosphoprotein) is suitable for studies of normal and adenomatous parathyroid tissues.

\section{Expression of parathyroid-related genes}

In the array analyses, Group I adenomas showed lower levels of PTH expression as compared with Group II adenomas. Since the PTH gene is located in $11 \mathrm{p} 15$, the lower expression might be explained by a reduced dose effect following loss of a chromosome 11 homologue in Group I adenomas. Two receptors of main 
Table 5 Genes showing significantly differential mean expression levels in parathyroid adenomas with 11 q13 LOH (Group I) vs adenomas without 11q13 LOH (Group II).

\begin{tabular}{|c|c|c|c|c|c|}
\hline $\begin{array}{l}\text { Accession } \\
\text { number }\end{array}$ & $\begin{array}{l}\text { Gene } \\
\text { symbol }\end{array}$ & $\begin{array}{l}\text { Chromosomal } \\
\text { location }\end{array}$ & $\begin{array}{c}\text { GO biological } \\
\text { process description }\end{array}$ & $\begin{array}{l}\text { Relative expression } \\
\text { (Group I/Group II) }\end{array}$ & $\boldsymbol{P}$ \\
\hline \multicolumn{6}{|c|}{ High expression in adenoma: Group I } \\
\hline AL049654 & PRKCABP & $22 \mathrm{q} 13.1$ & Amino acid phosphorylation & $1.2 / 1.0$ & 0.0001 \\
\hline U77948 & GTF2I & $7 q 11.23$ & Regulation of transcription & $1.4 / 1.0$ & 0.0004 \\
\hline U07231 & GRSF1 & $4 q 13$ & & $1.3 / 1.0$ & 0.0005 \\
\hline AF059611 & ENC1 & $5 q 12-q 13.3$ & Neurogenesis & $19.6 / 1.0$ & 0.0005 \\
\hline AL050166 & $C Y L D$ & $16 q 12.1$ & & $1.9 / 1.0$ & 0.0006 \\
\hline D86981 & APPBP2 & $17 q 21-q 23$ & Intracellular protein transport & $1.4 / 1.0$ & 0.0006 \\
\hline AL031714 & UBE21 & $16 \mathrm{p} 13.3$ & Protein modification & $2.3 / 1.0$ & 0.0007 \\
\hline U23803 & HNRPAO & $5 q 31$ & mRNA processing & $1.7 / 1.0$ & 0.0007 \\
\hline AB015344 & UBQLN2 & Xp11.23 & & $1.7 / 1.0$ & 0.0007 \\
\hline AL021786 & ITM2A & Xp13.3-Xq21.2 & & $2.2 / 1.0$ & 0.0008 \\
\hline X01630 & ASS & $9 q 34.1$ & & $1.4 / 1.0$ & 0.0009 \\
\hline Z283840 & NHP2L1 & $22 \mathrm{q} 13.2-\mathrm{q} 13.31$ & Regulation of cell cycle & $1.5 / 1.0$ & 0.0010 \\
\hline D87075 & $S L C 23 A 1$ & $20 \mathrm{p} 13$ & Sodium ion transport & $1.5 / 1.0$ & 0.0011 \\
\hline AL080097 & C3orf4 & $3 p 11-q 11$ & & $1.3 / 1.0$ & 0.0012 \\
\hline X96924 & SLC25A1 & $22 q 11.21$ & Mitochondrial transport & $1.3 / 1.0$ & 0.0012 \\
\hline S67247 & MYH10 & $17 \mathrm{p} 13.1$ & Cytokinesis & $1.6 / 1.0$ & 0.0012 \\
\hline AL049981 & WBP2 & $17 q 25$ & Signal transduction & $1.4 / 1.0$ & 0.0013 \\
\hline M69013 & GNA11 & $19 p 13.3$ & & $1.7 / 1.0$ & 0.0014 \\
\hline AF072810 & $B A Z 1 B$ & $7 q 11.23$ & Regulation of transcription & $1.6 / 1.0$ & 0.0015 \\
\hline D16481 & $H A D H B$ & $2 p 23$ & Fatty acid metabolism & $2.0 / 1.0$ & 0.0017 \\
\hline AL041663 & $M D C 1$ & 6pter-p21.31 & & $1.9 / 1.0$ & 0.0017 \\
\hline AB002347 & C6orf133 & $6 \mathrm{p} 21.1$ & Ubiquitin cycle transport & $1.3 / 1.0$ & 0.0017 \\
\hline AL080113 & KDELR3 & $22 \mathrm{q} 13.1$ & Intracellular prot transport & $1.6 / 1.0$ & 0.0018 \\
\hline D21851 & LARS2 & 3p21.3 & Leucyl-tRNA aminoacylation & $1.4 / 1.0$ & 0.0018 \\
\hline AB018264 & TSPYL4 & $6 q 22.31$ & Nucleosome assembly & $1.6 / 1.0$ & 0.0018 \\
\hline AB017019 & HNRPDL & $4 q 13-q 21$ & RNA processing & $1.3 / 1.0$ & 0.0020 \\
\hline U91641 & SIAT8E & $18 \mathrm{q} 12.3-\mathrm{q} 21.1$ & Amino acid glycosylation & $16.0 / 1.0$ & 0.0020 \\
\hline D67029 & SEC14L1 & $17 q 25.1$ & Transport & $1.7 / 1.0$ & 0.0020 \\
\hline AF002697 & BNIP3 & $14 q 11.2-q 12$ & Anti-apoptosis & $2.0 / 1.0$ & 0.0021 \\
\hline AJ243310 & AHSA1 & $14 \mathrm{q} 23.3-31$ & & $1.3 / 1.0$ & 0.0022 \\
\hline U66309 & $R X R A$ & $9 \mathrm{q} 34.3$ & Signal transduction & $1.6 / 1.0$ & 0.0023 \\
\hline D50929 & EIF3S10 & $10 q 26$ & Regulation of translation & $1.4 / 1.0$ & 0.0024 \\
\hline M26683 & CCL2 & $17 q 11.2-q 21.1$ & Amino acid phosphorylation etc. & $1.9 / 1.0$ & 0.0025 \\
\hline U28389 & EPB49 & $8 p 21.1$ & Cytoskeleton biosyntes & $1.4 / 1.0$ & 0.0025 \\
\hline D87466 & KIAA0276 & $4 \mathrm{p} 12$ & & $1.9 / 1.0$ & 0.0025 \\
\hline D87119 & TRB2 & $2 \mathrm{p} 25.1$ & Amino acid phosphorylation & $1.9 / 1.0$ & 0.0026 \\
\hline AB007855 & TIX1 & $20 q 12$ & Regulation of transcription & $2.1 / 1.0$ & 0.0027 \\
\hline X81625 & ETF1 & $5 q 31.1$ & Regulation of translation & $1.3 / 1.0$ & 0.0029 \\
\hline L17131 & HMGA1 & $6 \mathrm{p} 21$ & Regulation of transcription & $1.6 / 1.0$ & 0.0029 \\
\hline AL022326 & SYNGR1 & $22 q 13.1$ & & $2.8 / 1.0$ & 0.0029 \\
\hline AB014512 & BZRAP1 & $17 q 22-q 23$ & & $2.5 / 1.0$ & 0.0031 \\
\hline \multicolumn{6}{|c|}{ Lower expression in adenoma: Group 1} \\
\hline AF042386 & PPIE & $1 \mathrm{p} 32$ & Regulation of transcription & $0.58 / 1.0$ & 0.0001 \\
\hline X92814 & HRASLS3 & $11 q 13.1$ & & $0.14 / 1.0$ & 0.0001 \\
\hline AF052149 & $B S C L 2$ & $11 q 12-q 13.5$ & & $0.57 / 1.0$ & 0.0002 \\
\hline M55409 & EEFIG & $11 \mathrm{q} 13.2$ & & $0.58 / 1.0$ & 0.0002 \\
\hline U39400 & MRPL49 & $11 q 13$ & Cell growth & $0.67 / 1.0$ & 0.0002 \\
\hline Al033692 & $B A N F 1$ & $11 \mathrm{q} 13.1$ & Virus response & $0.59 / 1.0$ & 0.0002 \\
\hline U60644 & PLD3 & $19 \mathrm{q} 13.2$ & Metabolism & $0.50 / 1.0$ & 0.0002 \\
\hline X65923 & $F A U$ & $11 \mathrm{q} 13$ & Protein biosynthesis & $0.49 / 1.0$ & 0.0003 \\
\hline X05323 & MOX2 & $3 q 12-q 13$ & & $0.18 / 1.0$ & 0.0003 \\
\hline X02344 & & 9 & & $0.75 / 1.0$ & 0.0004 \\
\hline HG1614-HT1614 & & & & $0.50 / 1.0$ & 0.0005 \\
\hline AF022813 & TM4SF7 & $11 \mathrm{p} 15.5$ & Protein assembly & $0.78 / 1.0$ & 0.0005 \\
\hline AF018631 & $B T D$ & $3 p 25$ & CNS development etc. & $0.59 / 1.0$ & 0.0005 \\
\hline X81372 & $B P H L$ & $6 \mathrm{p} 25$ & Amino acid metabolism & $0.67 / 1.0$ & 0.0006 \\
\hline AL050204 & & $11 \mathrm{q} 22.3$ & & $0.47 / 1.0$ & 0.0007 \\
\hline AW044624 & $R E R 1$ & 1pter-q24 & ER transport & $0.56 / 1.0$ & 0.0007 \\
\hline D29643 & DDOST & $1 \mathrm{p} 36.1$ & $\mathrm{~N}$-linked glycosylation & $0.62 / 1.0$ & 0.0007 \\
\hline U43368 & VEGFB & $11 \mathrm{q} 13$ & Regulation of cell growth & $0.48 / 1.0$ & 0.0007 \\
\hline W26480 & FADS1 & $11 \mathrm{q} 12.2-\mathrm{q} 13.1$ & & $0.47 / 1.0$ & 0.0011 \\
\hline L13687 & SNX15 & $11 \mathrm{q} 13$ & Protein transport and signalling & $0.80 / 1.0$ & 0.0012 \\
\hline
\end{tabular}

Table 5 continued on following page 
Table 5 Continued.

\begin{tabular}{|c|c|c|c|c|c|}
\hline $\begin{array}{l}\text { Accession } \\
\text { number }\end{array}$ & $\begin{array}{l}\text { Gene } \\
\text { symbol }\end{array}$ & $\begin{array}{l}\text { Chromosomal } \\
\text { location }\end{array}$ & $\begin{array}{l}\text { GO biological } \\
\text { process description }^{a}\end{array}$ & $\begin{array}{l}\text { Relative expression } \\
\text { (Group I/Group II) }\end{array}$ & $\boldsymbol{P}$ \\
\hline AF043325 & NMT2 & $10 p 12.33$ & Protein myristoylation & $0.40 / 1.0$ & 0.0012 \\
\hline U62961 & $O X C T$ & $5 p 13$ & Succinyl-CoA metabolism & $0.43 / 1.0$ & 0.0013 \\
\hline AL080190 & & $8 p 23.1$ & & $0.86 / 1.0$ & 0.0017 \\
\hline AA845349 & HMGN3 & $6 q 15$ & Regulation of transcription & $0.83 / 1.0$ & 0.0020 \\
\hline M15036 & PROS1 & $3 p 11-q 11.2$ & Blood coagulation & $0.31 / 1.0$ & 0.0020 \\
\hline U52427 & POLR2G & $11 q 13.1$ & Nucleotide-excision repair & $0.49 / 1.0$ & 0.0020 \\
\hline AA158243 & $F K B P 2$ & $11 q 13.1-q 13.3$ & Protein folding & $0.45 / 1.0$ & 0.0022 \\
\hline M62895 & $A N \times A 2 P 3$ & $10 q 21-q 22$ & Skeletal development & $0.34 / 1.0$ & 0.0023 \\
\hline AF010187 & FIBP & $11 \mathrm{q} 13.1$ & FGF receptor signaling & $0.55 / 1.0$ & 0.0023 \\
\hline U66879 & $B A D$ & $11 q 13.1$ & Apoptosis & $0.37 / 1.0$ & 0.0024 \\
\hline U90916 & SORL1 & $11 \mathrm{q} 23.3$ & Lipid transport & $0.39 / 1.0$ & 0.0025 \\
\hline AB020637 & KIAA0830 & $11 \mathrm{q} 21$ & & $0.48 / 1.0$ & 0.0025 \\
\hline AL050089 & $B A Z I A$ & $14 q 12-q 13$ & Regulation of transcription & $0.54 / 1.0$ & 0.0025 \\
\hline AA917672 & ATP5L & $3 q 27$ & ATP biosynthesis & $0.64 / 1.0$ & 0.0025 \\
\hline Y14155 & $M O B$ & $10 q$ & & $0.41 / 1.0$ & 0.0026 \\
\hline D00017 & ANXA2 & $15 q 21-q 22$ & Skeletal development & $0.31 / 1.0$ & 0.0027 \\
\hline L37043 & CSNK1E & $22 q 13.1$ & DNA repair and amino acid phosphorylation & $0.68 / 1.0$ & 0.0029 \\
\hline AF038406 & NDUFS8 & $11 q 13$ & Mitochondrial transport & $0.47 / 1.0$ & 0.0030 \\
\hline L40397 & TMP21 & $14 q 24.3$ & ER transport & $0.52 / 1.0$ & 0.0030 \\
\hline AL050008 & BRMS1 & $11 q 13-q 13.2$ & & $0.52 / 1.0$ & 0.0031 \\
\hline D12676 & SCARB2 & $4 q 21.1$ & Cell adhesion & $0.57 / 1.0$ & 0.0031 \\
\hline U93237 & MEN1 & $11 q 13$ & Regulation of transcription & $0.25 / 1.0$ & 0.0031 \\
\hline S57501 & PPP1CA & $11 q 13$ & Amino acid dephosphorylation & $0.56 / 1.0$ & 0.0031 \\
\hline M68864 & LOC51035 & $11 \mathrm{q} 13.1$ & & $0.70 / 1.0$ & 0.0031 \\
\hline
\end{tabular}

$t$-tests were performed by comparing the mean expression levels between the groups of adenomas with $11 \mathrm{q} 13 \mathrm{LOH}$ and without $11 \mathrm{q} 13 \mathrm{LOH}$ using the dChip software. ${ }^{a}$ Gene ontology description according to the NetAffxTM analysis center: http://www.affymetrix.com/analysis/index.affx. The genes are listed by ascending $P$ values. ER, estrogen receptor.

interest for parathyroid tumorigenesis are CASR and $V D R$. Both these receptors showed a distinct pattern of under-expression in all adenomas as compared with the normal parathyroids (Table 3). Both CASR and VDR participate in the calcium homeostasis controlled by the parathyroid gland, and it is suggested that the reduced expression of CASR and VDR has a major impact on the altered calcium homeostasis in PHPT. Our array data regarding CASR expression (median 63\%, range $43-80 \%$ ) correlate well with the mRNA in situ data previously published which also showed reduced expression in adenomas vs normal parathyroid (reduced to median $64 \%$, range $41-98 \%$ ) (10). Furthermore, in our study the VDR expression was reduced in the adenomas (to median $47 \%$, range 20-64\%) compared with the expression in normal parathyroid tissue. A similar pattern of VDR underexpression in parathyroid adenomas was also reported by Carling et al. (27). The consistent reduced levels of both VDR and CASR expression are of interest given the recent demonstration that the CASR gene promoters have vitamin D response elements (VDREs) that confer transcriptional responsiveness to 1,25-dihydroxyvitamin D levels (28).

\section{Expression profiles in parathyroid adenomas with and without 11 q13 LOH}

In order to display potential parathyroid adenoma subgroups, we performed an 'unsupervised' clustering ana- lysis, in which no external input was used to guide the analysis process. We used the most common unsupervised analysis method, i.e. hierarchical cluster analysis (29). This method is used to search for patterns without any expectation concerning the number or type of groups that creates the dendogram, as illustrated in Fig. 1A. The resulting hierarchical tree demonstrated that the adenomas clustered together in two individual groups. Group I consisted of the four adenomas with $11 q 13 \mathrm{LOH}$ and Group II of the four adenomas without $11 \mathrm{q} 13 \mathrm{LOH}$ (Fig. 1A). In addition, several genes were detected with a significantly $(P<0.0032)$ distinct expression profile in Group I and II (Table 5). Among the genes over-expressed in Group I can be noted ENC1 (5q12-q13.3), which showed 20-fold increase compared with Group II. This may reflect an important downstream effect. ENC1 is over-expressed in primary colon cancer, neuroblastoma and haircell leukemia (30). Functional in vitro assays suggest that the p53 inducible ENC1 is regulated by the $\beta$-catenin/Tcf pathway, and that its over-expression stimulates proliferation and suppresses differentiation. The present series of tumors is too limited in number to draw conclusions about clinical phenotypes and expression profiles. However, it has been suggested that sporadic and MEN 1-associated parathyroid tumors with $\mathrm{LOH}$ of the MEN1 locus in $11 \mathrm{q} 13$ are larger than tumors without this abnormality (14).

Approximately $50 \%$ of the under-expressed genes in Group I are located on chromosome 11 suggesting an 
underlying gene dose effect (Table 5 and Fig. 1B). This hypothesis was substantiated by the demonstration of loss of the entire chromosome 11 by CGH. The results suggest that adenomas in Group I have partly similar and partly distinguishing expression profiles as compared with the Group II adenomas. The distinct expression profiles would suggest that adenomas with 11 q13 LOH partly affect different pathways as compared with the adenomas without LOH. Nevertheless, another set of genes showed similarly differential expression in the entire adenoma group as compared with normal parathyroid. This may result from late downstream effects in common for tumor development of most adenomas, e.g. over-expression of Cyclin D1 and c-Jun. The common alterations could also represent secondary effects of the tumor status or altered calcium homeostasis. The reduced expression observed for, for example CASR and VDR, would preferentially be placed in this last category. PHPT is clearly a heterogenous disease both regarding clinical development and molecular genetic alterations. Although the biological effect of the altered expression pattern is difficult to survey, it can be speculated that partly different molecular pathways could lead to benign tumor development in the parathyroid gland.

In summary, we have shown that genetic subsets in parathyroid adenomas distinguished by the 11q13 LOH status are reflected in the gene expression profiles, but that commonly altered gene expression patterns are also evident. In the future, detailed analysis at the protein level will help us to understand the impact on tumorigenesis of the genes identified in this study.

\section{Acknowledgements}

The authors are grateful to Lisa Åhnfalk for excellent technical assistance in handling the tumor samples. The study was financially supported by grants from Torsten and Ragnar Söderberg Foundations, Swedish Cancer Foundation, Stockholm Cancer Society, Gustav V Jubilee Foundation, Vera and Emil Cornell Foundation, Milton Foundation, Stockholm County Council, Fredrik and Ingrid Thuring Foundataion and Wallenberg Consortium North.

\section{References}

1 Chandrasekharappa SC, Guru SC, Manickam P, Olufemi SE, Collins FS, Emmert-Buck MR, Debelenko LV, Zhuang Z, Lubensky IA, Liotta LA, Crabtree JS, Wang Y, Roe BA, Weisemann J, Boguski MS, Agarwal SK, Kester MB, Kim YS, Heppner C, Dong Q, Spiegel AM, Burns AL \& Marx SJ. Positional cloning of the gene for multiple endocrine neoplasia-type 1 . Science $1997 \mathbf{2 7 6} 404-407$.

2 Teh BT, Esapa CT, Houlston R, Grandell U, Farnebo F, Nordenskjöld M, Pearce CJ, Carmichael D, Larsson C \& Harris PE. A family with isolated hyperparathyroidism segregating a missense MEN1 mutation and showing loss of the wild- type alleles in the parathyroid tumors. American Journal of Human Genetics $1998631544-1549$.

3 Carpten JD, Robbins CM, Villablanca A, Forsberg L, Presciuttini S, Bailey-Wilson J, Simonds WF, Gillanders EM, Kennedy AM, Chen JD, Agarwal SK, Sood R, Jones MP, Moses TY, Haven C, Petillo D, Leotlela PD, Harding B, Cameron D, Pannett AA, Höög A, Heath H, James-Newton LA, Robinson B, Zarbo RJ, Cavaco BM, Wassif W, Perrier ND, Rosen IB, Kristoffersson U, Turnpenny PD, Farnebo L-O, Besser GM, Jackson CE, Morreau H, Trent JM, Thakker RV, Marx SJ, Teh BT, Larsson C \& Hobbs MR. HRPT2, encoding parafibromin, is mutated in hyperparathyroidism-jaw tumor syndrome. Nature Genetics $200232676-680$.

4 Carling T, Szabo E, Bai M, Ridefelt P, Westin G, Gustavsson P, Trivedi S, Hellman P, Brown EM, Dahl N \& Rastad J. Familial hypercalcemia and hypercalciuria caused by a novel mutation in the cytoplasmic tail of the calcium receptor. Journal of Clinical Endocrinology and Metabolism 200085 2042-2047.

5 Villablanca A, Calender A, Forsberg L, Höög A, Cheng JD, Petillo D, Bauters C, Kahnoski K, Ebeling T, Salmela P, Richardson AL, Delbridge L, Meyrier A, Proye C, Carpten JD, Teh BT, Robinson BG \& Larsson C. Germline and de novo mutations in the HRPT2 tumour suppressor gene in familial isolated hyperparathyroidism (FIHP). Journal of Medical Genetics 200441 e32.

6 Heppner C, Kester MB, Agarwal SK, Debelenko LV, EmmertBuck MR, Guru SC, Manickam P, Olufemi SE, Skarulis MC, Doppman JL, Alexander RH, Kim YS, Saggar SK, Lubensky IA, Zhuang Z, Liotta LA, Chandrasekharappa SC, Collins FS, Spiegel AM, Burns AL \& Marx SJ. Somatic mutation of the MEN1 gene in parathyroid tumours. Nature Genetics 199716 375-378.

7 Howell VM, Haven CJ, Kahnoski K, Khoo SK, Petillo D, Chen J, Fleuren GJ, Robinson BG, Delbridge LW, Philips J, Nelson AE, Krause U, Hammje K, Dralle H, Hoang-Vu C, Gimm O, Marsh DJ, Morreau H \& Teh BT. HRPT2 mutations are associated with malignancy in sporadic parathyroid tumours. Journal of Medical Genetics $2003 \mathbf{4 0} 657-663$.

8 Shattuck TM, Välimäki S, Obara T, Gaz RD, Clark OH, Shoback D, Wierman ME, Tojo K, Robbins CM, Carpten JD, Farnebo L-O, Larsson C \& Arnold A. Somatic and germ-line mutations of the HRPT2 gene in sporadic parathyroid carcinoma. New England Journal of Medicine $20033491722-1729$.

9 Arnold A, Kim HG, Gaz RD, Eddy RL, Fukushima Y, Byers MG, Shows TB \& Kronenberg HM. Molecular cloning and chromosomal mapping of DNA rearranged with the parathyroid hormone gene in a parathyroid adenoma. Journal of Clinical Investigation $1989832034-2040$.

10 Farnebo F, Enberg U, Grimelius L, Bäckdahl M, Schalling M, Larsson C \& Farnebo L-O. Tumor-specific decreased expression of calcium sensing receptor messenger ribonucleic acid in sporadic primary hyperparathyroidism. Journal of Clinical Endocrinology and Metabolism $1997 \mathbf{8 2} 3481-3486$.

11 Carling T, Kindmark A, Hellman P, Lundgren E, Ljunghall S, Rastad J, ̊̊kerström G \& Melhus H. Vitamin D receptor genotypes in primary hyperparathyroidism. Nature Medicine $1995 \mathbf{1}$ 1309-1311.

12 Palanisamy N, Imanishi Y, Rao PH, Tahara H, Chaganti RS \& Arnold A. Novel chromosomal abnormalities identified by comparative genomic hybridization in parathyroid adenomas. Journal of Clinical Endocrinology and Metabolism 199883 1766-1770.

13 Farnebo F, Kytölä S, Teh BT, Dwight T, Wong FK, Höög A, Elvius M, Wassif WS, Thompson NW, Farnebo L-O, Sandelin K \& Larsson C. Alternative genetic pathways in parathyroid tumorigenesis. Journal of Clinical Endocrinology and Metabolism $1999 \mathbf{8 4}$ 3775-3780.

14 Friedman E, De Marco L, Gejman PV, Norton JA, Bale AE, Aurbach GD, Spiegel AM \& Marx SJ. Allelic loss from chromosome 11 in parathyroid tumors. Cancer Research $1992526804-6809$. 
15 Farnebo F, Teh BT, Kytölä S, Svensson A, Phelan C, Sandelin K, Thompson NW, Höög A, Weber G, Farnebo L-O \& Larsson C. Alterations of the MEN1 gene in sporadic parathyroid tumors. Journal of Clinical Endocrinology and Metabolism $1998 \mathbf{8 3}$ $2627-2630$.

16 Tahara H, Smith AP, Gas RD, Cryns VL \& Arnold A. Genomic localization of novel candidate tumor suppressor gene loci in human parathyroid adenomas. Cancer Research $1996 \mathbf{5 6}$ 599-605.

17 Solcia E, Klöppel G \& Sobin LH. Histological classification of tumours of the parathyroid gland. In Histological Typing of Endocrine Tumors, edn 2, pp 48-55, Heidelberg: Springer-Verlag, 2000.

18 Li C \& Wong WH. Model-based analysis of oligonucleotide arrays: expression index computation and outlier detection. PNAS 2001 $9831-36$.

19 Juneja HS, Lee S, Thomazy V, Shipley G \& Davies PJ. Acute activation of gp130 gene expression in bone marrow stromal cells by contact with myeloma-derived lymphoblastic cell line ARH77 cell membranes. Journal of Interferon and Cytokine Research 2001 21 157-166.

20 Hemmer S, Wasenius VM, Haglund C, Zhu Y, Knuutila S, Franssila K \& Joensuu H. Deletion of 11q23 and cyclin D1 overexpression are frequent aberrations in parathyroid adenomas. American Journal of Pathology 2001158 1355-1362.

21 Hsi ED, Zukerberg LR, Yang WI \& Arnold A. Cyclin D1/PRAD1 expression in parathyroid adenomas: an immunohistochemical study. Journal of Clinical Endocrinology and Metabolism $1996 \mathbf{8 1}$ 1736-1739.

22 Arnold A. Genetic basis of endocrine disease 5. Molecular genetics of parathyroid gland neoplasia. Journal of Clinical Endocrinology and Metabolism 199377 1108-1112.

23 Eferl R, Ricci R, Kenner L, Zenz R, David JP, Rath M \& Wagner EF. Liver tumor development. c-Jun antagonizes the proapoptotic activity of p53. Cell $2003112181-192$.
24 Mechta-Grigoriou F, Gerald D \& Yaniv M. The mammalian Jun proteins: redundancy and specificity. Oncogene 200120 2378-2389.

25 Agarwal SK, Guru SC, Heppner C, Erdos MR, Collins RM, Park SY, Saggar S, Chandrasekharappa SC, Collins FS, Spiegel AM, Marx SJ \& Burns AL. Menin interacts with the AP1 transcription factor JunD and represses JunD-activated transcription. Cell 199996 $143-152$.

26 Gallo A, Cuozzo C, Esposito I, Maggiolini M, Bonofiglio D, Vivacqua A, Garramone M, Weiss C, Bohmann D \& Musti AM. Menin uncouples Elk-1, JunD and c-Jun phosphorylation from MAP kinase activation. Oncogene 200221 6434-6445.

27 Carling T, Rastad J, Szabo E, Westin G \& Åkerström G. Reduced parathyroid vitamin D receptor messenger ribonucleic acid levels in primary and secondary hyperparathyroidism. Journal of Clinical Endocrinology and Metabolism 200085 2000-2003.

28 Canaff L \& Hendy GN. Human calcium-sensing receptor gene. Vitamin D response elements in promoters P1 and P2 confer transcriptional responsiveness to 1,25-dihydroxyvitamin D. Journal of Biological Chemistry 2002277 30337-30350. Epub 32002 May 30329.

29 Eisen MB, Spellman PT, Brown PO \& Botstein D. Cluster analysis and display of genome-wide expression patterns. PNAS 199895 14863-14868.

30 Fujita M, Furukawa Y, Tsunoda T, Tanaka T, Ogawa M \& Nakamura Y. Up-regulation of the ectodermal-neural cortex 1 (ENC1) gene, a downstream target of the beta-catenin/T-cell factor complex, in colorectal carcinomas. Cancer Research 2001 $617722-7726$.

Received 25 August 2004

Accepted 14 December 2004 